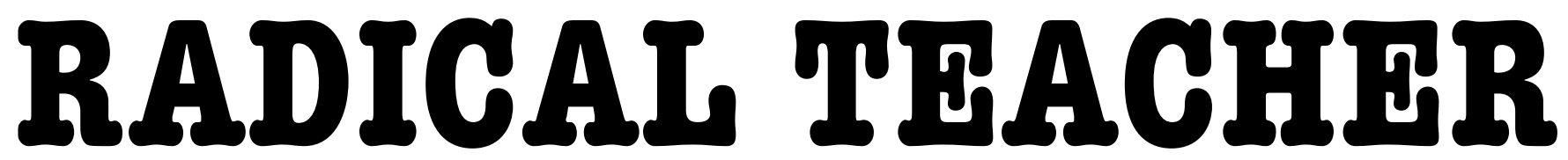

A SOCIALIST, FEMINIST, AND ANTI-RACIST JOURNAL ON THE THEORY AND PRACTICE OF TEACHING

\title{
Reflections of a Transgender Medievalist
}

(RADICAL TEACHER NO.77, 2006)

by Angelique Davi

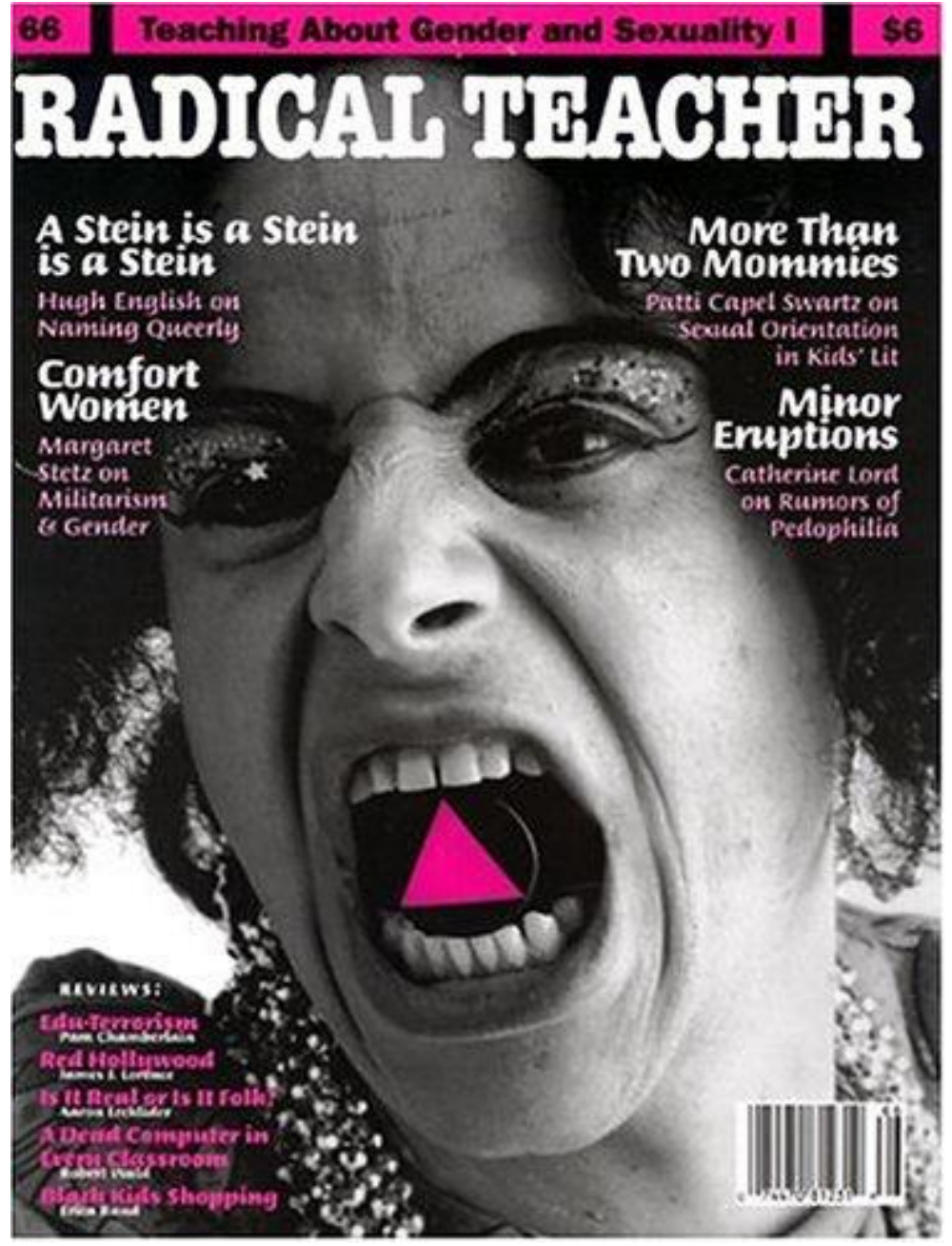

RADICAL TEACHER, ISSUE 66 
I am a gender-bending lesbian who teaches Beowulf at a business university. In this piece, I reflect on an incident that reminds me I have little control over where and when my identity becomes more or less prominent for my students. Because the incident took me by surprise, I failed to capitalize on a teachable moment; this piece is my attempt at making sense of that failure.

The specific incident took place while I traveled through London with eleven students in my "Chaucer's World" course. One evening, as my students and I rode an escalator to the Tube, a man passed us and stared at me with a penetrating gaze. As he got closer, he yelled to the students, "Get away from this one who appears to be a man. He...she...it... will lead you all to damnation." I could feel his breath on me as he screamed. He implored the students to get away from me, screaming about hell and damnation and my appearing to be both "man and woman."

This was not the first time I was accosted for being transgender. I have been chased down the streets and have had people stare at me in anger as I enter public restrooms. A cab driver in Kalamazoo spent the entire thirty- minute ride to the airport preaching to me to redeem my sins lest I burn in the flames of hell for all eternity.

That evening on the escalator in London, my students did a noble thing. Before we landed at the bottom, five of them surrounded me on every side. By the time we reached the attacker who stood waiting for us, my students were acting as a shield protecting me from him. As we walked down the corridor to the next escalator, my students held their positions. The attacker continued to scream obscenities about my gender, but my students didn't budge. We traveled through the Tube system like this until my attacker eventually got frustrated enough to move on. As he headed down a different corridor, my students asked if I was OK and, when assured, continued toward the train platform. Briefly, before the train arrived, I talked to them about this being a somewhat typical occurrence in my life and apologized to them for their having to be witness to this. They were relatively short on words.

I felt tremendous guilt after the incident. As is the case with many victims of abuse, I blamed myself. I repeatedly asked myself what I could have done differently. My job was to lead my students through medieval sites in England; it was not to expose them to the hostility I experience, on a rather frequent basis, because of my gender bending. I blamed myself for making my students vulnerable to harm because of my choice of attire and hairstyle. After that brief conversation on the train platform, I never raised the topic with my students again. I regret that choice, and I continue to struggle to understand why I was unable to address the incident with them. But in terms of the personal, at the time, I could not articulate to my students fully who I am and why
I make the choices in my appearance that I do. I doubted I would have any good answers to their questions.

So much had passed between us in those brief moments in the London Underground, but it would go unprocessed by us as a group, as a class. I discovered, through one student, that the class came together in a pub and spent much of the evening discussing what had transpired. The discussion focused on what it felt like for each of them to be victims of abuse and what it felt like to hear me tell them that that was not an unusual occurrence in my life. Despite the absence of a formal reflection assignment, my students chose to process the incident in their own way -- together when I was not with them.

In surrounding me on the escalators, my students made a choice to put me before themselves. They let me know, with their body movements, that they respected me. In some ways, my gender bending created a moment of possibility which I could not control. And my students seized the opportunity. Many of them walked away from the course being able to recite in Middle English the opening to Chaucer's Canterbury Tales. But I suspect they also took away a lesson that was equally important and one for which I couldn't have prepared. (c)) EY-NC-ND

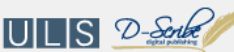

This work is licensed under a Creative Commons Attribution-Noncommercial-No Derivative Works 3.0 United States License.

This journal is published by the University Library System of the University of Pittsburgh as part of its D-Scribe Digital Publishing Program, and is cosponsored by the University of Pittsburgh Press.
RADICAL TEACHER
No. 113 (Winter 2019) 